\title{
Potential nutritional and physiological functions of betaine in livestock
}

\author{
M. Eklund, E. Bauer, J. Wamatu and R. Mosenthin* \\ Institute of Animal Nutrition, University of Hohenheim, Emil-Wolff-Strasse 10, D-70599 Stuttgart, Germany
}

\begin{abstract}
The present review summarises the potential nutritional and physiological functions of betaine as a feed additive in relation to performance criteria in livestock production. Betaine, the trimethyl derivative of the amino acid glycine, is a metabolite of plant and animal tissues. In plants, betaine is particularly synthesised and accumulated as an osmoprotectant against salt and temperature stress. In animals, betaine is the product of choline oxidation or it originates from nutritional sources. Over the past decades, numerous studies have been carried out to investigate the potential effects of betaine supplementation on animal performance. Due to its chemical structure, betaine shows the characteristics of a dipolar zwitterion resulting in osmoprotective properties. Promoting effects on the intestinal tract against osmotic stress occurring during diarrhoea or coccidiosis have been reported following betaine supplementation in pigs and poultry. There is also some evidence that dietary betaine may improve the digestibility of specific nutrients. As a product of choline oxidation, betaine is involved in transmethylation reactions of the organism. Betaine as a methyl donor provides its labile methyl groups for the synthesis of several metabolically active substances such as creatine and carnitine. Supplementation with betaine may decrease the requirement for other methyl donors such as methionine and choline. There is also some evidence for enhanced methionine availability after dietary supplementation of betaine resulting in improved animal performance. Alterations in the distribution pattern of protein and fat in the body have been reported following betaine supplementation. A more efficient use of dietary protein may result from a methionine-sparing effect of betaine, but also direct interactions of betaine with metabolism-regulating factors have to be considered. Though the mode of action of betaine as a carcass modifier remains open, there is, however, growing evidence that betaine could have a positive impact both on animal performance and carcass quality.
\end{abstract}

Betaine: Osmolytes: Methyl donors: Performance: Carcass quality

\section{Introduction}

Betaine is the trimethyl derivative of the amino acid glycine. As a by-product of sugarbeet processing, betaine is commercially available as a feed additive. Due to its chemical structure (Fig. 1), various functions have been described for the betaine molecule. In plants (for example, Robinson \& Jones, 1986), bacteria (for example, Le Rudulier et al. 1984), and marine organisms (for example, Clarke et al. 1994), betaine is a widely distributed osmoprotectant. Also in higher vertebrates there is some evidence that betaine is used by numerous tissues as an osmolyte (for example, Law \& Burg, 1991). The osmotic activity of betaine has to be attributed to its dipolar zwitterion characteristics and its high solubility in water (Chambers \& Kunin, 1985). Furthermore, betaine provides three methyl groups which can be used in transmethylation reactions for the synthesis of numerous substances such as carnitine and creatine (for example, Kidd et al. 1997). Finally, by virtue of its chemical structure, betaine shows the characteristics of the amino acid glycine as well. Due to both its methyl donor and its amino acid function, betaine is involved in protein and energy metabolism. In animal nutrition, betaine is widely discussed as a 'carcass modifier' due to its lipotropic and growth-promoting effects. The objective of the present paper is to review the potential nutritional and physiological functions of betaine in ruminants and single-stomached animals.

\section{Dietary sources of betaine}

In plants and bacteria, betaine often is produced and accumulated in order to cope with salt and temperature stress (for example, Kuznetsov \& Shevyakova, 1997; Xing \& Rajashekar, 2001). In Table 1, the betaine content of selected feed ingredients is summarised. Sugarbeets contain

\footnotetext{
Abbreviations: BHMT, betaine-homocysteine-methyltransferase; GH, growth hormone; HC, homocysteine; SAM, S-adenosyl methionine; THFMT, tetrahydrofolate-methyltransferase.

* Corresponding author: Dr Rainer Mosenthin, fax +49 711459 2421, email rhmosent@uni-hohenheim.de
} 


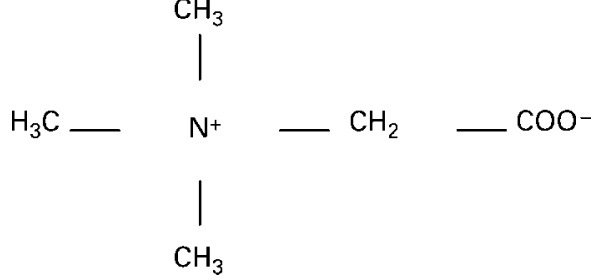

Fig. 1. Chemical structure of betaine.

exceptionally high levels of betaine which accumulate in condensed molasses solubles, a by-product of sugarbeet processing. In addition, considerable amounts of betaine have been found in wheat bran (Westberg, 1951) and wheat (E Virtanen, cited by Kidd et al. 1997). Nevertheless, betaine is also available as a feed additive in purified form. The most popular forms of feed-grade betaine are anhydrous betaine, betaine monophosphate and betaine hydrochloride. In terms of possible betaine effects in animal nutrition the chemical properties of these substances have to be recognised. Betaine hydrochloride shows lower solubility in water when compared with anhydrous betaine and betaine monohydrate (EU-Safety Data Sheet, 1999a,b,c), thereby reducing its osmolytic capacity. On the other hand, betaine hydrochloride supports the $\mathrm{pH}$ decline in the stomach, thereby potentially improving nutrient digestibility in a mode different from that of betaine. Since the purified forms of betaine commonly originate from the extraction of molasses solubles, the use the latter is also suggested as a dietary source of betaine. However, molasses solubles show high mineral contents which, in turn, may interfere with the osmolytic capacity of betaine.

\section{Physiological and nutritional functions of betaine}

\section{Betaine as an osmotic active substance}

In vertebrates, betaine accumulation is stimulated by external hyperosmolarity in the renal cells (Bagnasco et al. 1986; Nakanishi et al. 1990; Moeckel \& Lien, 1997) and macrophages (Warskulat et al. 1995; Zhang et al. 1996). Betaine also acts as an organic osmolyte in mouse embryos (Dawson \& Baltz, 1997), mouse hybridoma cells (Oyaas et al. 1995), rat liver sinusoidal epithelial cells (Weik et al. 1998; Wettstein et al. 1998), rat hepatic stellate cells (Peters-Regehr et al. 1999) and chick embryo fibroblasts (Tramacere et al. 1984; Petronini et al. 1992). Osmolytes are particularly important in situations of cellular dehydration since these compounds help to minimise water loss against a prevailing osmotic gradient (Klasing et al. 2002). Betaine exerts an osmoprotective effect by accumulating in cell organelles and cells exposed to osmotic and ionic stress, thereby replacing inorganic ions and protecting enzymes as well as cell membranes from inactivation by inorganic ions (Petronini et al. 1992). Changes in cell water volume are known to affect cell activity. For example, a slight increase in the volume of liver cells directs the cells into a more anabolic state, whereas the reverse may happen with loss of water (Haussinger, 1998). Thus, water homeostasis is an important factor for cells exposed to different osmotic pressures. Furthermore, it is known that endothelial cells exposed to a hyperosmotic media stop cell proliferation and undergo apoptosis (Alfieri et al. 2002). Betaine has been shown to exert anti-apoptotic effects and to promote cell proliferation in a hyperosmotic medium (Alfieri et al. 2002). Finally, there is some evidence that betaine reduces energy expenditure for ion pumping in cells exposed to hyperosmotic media (Moeckel et al. 2002). The spared energy may promote cell proliferation as well.

\section{Osmotic capacity of betaine in the gut}

Intestinal cells always have to cope with variable osmotic media since the luminal content of the intestine is hyperosmotic in relation to blood plasma (Mongin, 1976). Moreover, the process of nutrient digestion and absorption necessitates osmolytic protection mechanisms since intestinal cells mediate the exchange of water, small solutes such as ions, nutrients and macromolecules between plasma and intestinal fluid. Betaine is thought to be an important organic

Table 1. Betaine content of selected feed ingredients $(\mathrm{mg} / \mathrm{kg})$

\begin{tabular}{|c|c|c|}
\hline Feed ingredients & Betaine content & Reference \\
\hline Condensed molasses solubles & 116000 & M Eklund, J Wamatu, M Tafaj and R Mosenthin (unpublished results) \\
\hline Wheat & $\begin{array}{l}1400 \\
3960\end{array}$ & $\begin{array}{l}\text { E Virtanen cited by Kidd et al. } 1997 \\
\text { Chendrimada et al. }(2002)\end{array}$ \\
\hline Peas & 160 & Steinmetzer (1972) \\
\hline Groundnut meal & 2520 & Chendrimada et al. (2002) \\
\hline Wheat bran & 2675 & Westberg (1951) \\
\hline Wheat middlings & $\begin{array}{l}2675 \\
4980\end{array}$ & $\begin{array}{l}\text { Westberg (1951) } \\
\text { Chendrimada et al. (2002) }\end{array}$ \\
\hline Lucerne meal & $\begin{array}{l}3175-3850 \\
1770\end{array}$ & $\begin{array}{l}\text { Westberg (1951) } \\
\text { Chendrimada et al. (2002) }\end{array}$ \\
\hline Fish meal & $\begin{array}{l}400 \\
1180\end{array}$ & $\begin{array}{l}\text { E Virtanen (cited by Kidd et al. 1997) } \\
\text { Chendrimada et al. (2002) }\end{array}$ \\
\hline Oats & 590 & E Virtanen (cited by Kidd et al. 1997) \\
\hline Barley & 730 & E Virtanen (cited by Kidd et al. 1997) \\
\hline Rapeseed meal & Below detection limit & E Virtanen (cited by Kidd et al. 1997) \\
\hline Maize & Below detection limit & Westberg (1951), Chendrimada et al. (2002) \\
\hline Sesame meal & Below detection limit & Chendrimada et al. (2002) \\
\hline Soyabean meal & Below detection limit & Chendrimada et al. (2002) \\
\hline Soyabean meal & Below detection limit & E Virtanen (cited by Kidd et al. 1997) \\
\hline
\end{tabular}


osmolyte for the control of the osmotic pressure inside the intestinal epithelial cells (Hochachka \& Somero, 1984). Osmotic protection would allow for the maintenance of water balance and intestinal cell volume, thereby facilitating secretion of digestive enzymes. If betaine stimulates cell proliferation in the intestinal tissue, the enlarged gut wall epithelium would provide an increased surface for nutrient absorption. Effects of betaine as an osmotic active substance may be more pronounced in animals exposed to osmotic disorders such as coccidiosis in poultry.

\section{Betaine and coccidiosis}

Intestinal parasites commonly infect vertebrates, and coccidia are prevalent pathogens in chicks. These pathogens infect the intestinum and cause pathological lesions which are visible both macroscopically and microscopically. Malabsorption and diarrhoea are typical symptoms of coccidiosis. Betaine is known to positively influence water balance of broilers exposed to coccidia (Teeter et al. 1999), and to reduce faecal water content in turkeys (Ferket, 1995) and broilers (Remus et al. 1995). Reductions in faecal water content and decreased morbidity have been reported in weaned pigs as well ( $\mathrm{Xu} \& \mathrm{Yu}, 2000)$. The results of some investigations with broiler chicks even showed that betaine might improve the efficacy of coccidiostats as indicated by improved animal performance (for example, Virtanen et al. 1993; Augustine et al. 1997). Ionophore coccidiostats as such disturb the osmotic balance of the gut which may be attenuated by dietary betaine. Augustine et al. (1997) suggested that betaine may contribute to the improved performance of coccidian-infected chicks directly, by partial inhibition of coccidial invasion and development, and indirectly, by an improvement of the intestinal structure and function in the presence of a coccidial infection. This improvement of the intestinal structure might occur in both infected and healthy animals, and may affect nutrient digestibility.

\section{Effect of betaine on gut development and nutrient digestibility of healthy and infected animals}

\section{Betaine and gut development}

There is convincing evidence that betaine supports intestinal growth and function. Betaine accumulation results in an increased water-binding capacity of the intestinal cells (Kettunen et al. 2001a) and promotes changes in the structure of the gut epithelium. Enhanced tensile structure has been reported in chicks (Remus \& Quarles, 2000) and gut strength was improved in pigs (Siljander-Rasi et al. 2003). Fernandez-Figares et al. (2002) showed that supplemental betaine at a level of $0.125 \%$ increased small-intestinal weights of pigs, whereas at higher levels a decrease in the weight of the small intestine was reported. According to $\mathrm{Xu} \& \mathrm{Yu}(2000)$, the villus height is increased in the duodenum of weaned pigs, and the villi are more uniform following dietary betaine supplementation. Klasing et al. (2002) showed in chicks that the reduction of villus height caused by coccidia infection is reduced after dietary betaine supplementation. According to Kettunen et al. (2001c), supplemental betaine results in a decrease in the crypt:villus ratio in both coccidian-infected and healthy chicks, and the lesion score is reduced in coccidian-infected chicks (Virtanen \& Rosi, 1995). Since the process of nutrient digestion and absorption is dependent on an intact gut epithelium, the osmolytic capacity of betaine might positively affect digestibility.

There is convincing evidence that betaine is highly digestible when fed to pigs. Studies by Weigand \& Kirchgessner (1981) showed that betaine originating from condensed molasses solubles is completely absorbed in the gastrointestinal tract. In addition, these authors reported that about three-quarters of the absorbed betaine are retained. It has to be emphasised, however, that the total level of betaine in this study amounted to more than $3 \%$ which is considerably higher than average dietary betaine levels originating from other native sources (Table 1) or from purified betaine (Tables 2 to 7). It remains open whether the digestibility and absorption of betaine is dependent on the source and level of betaine in the diet. According to Kettunen et al. (2001c), most of the betaine in purified form is absorbed by the mid-jejunum in broiler chicks. However, there is a lack of information about the digestibility and absorption of betaine originating from feed ingredients other than sugarbeet by-products. Since betaine molecules originating from plant tissues show a high degree of solubility in water (for example, Bessieres et al. 1999), it can be assumed that native betaine from other dietary sources is also highly absorbable. However, part of the betaine in plant tissues might also be enclosed in cell-wall materials, thereby escaping digestion and absorption from the intestinal tract. According to Kettunen et al. (2001b), intestinal uptake of betaine originating from wheat is slower compared with purified betaine. Since the addition of purified betaine to betaine-rich diets showed positive effects on growth performance (for example, Cromwell et al. 1999), it can be assumed that there exist differences in availability between native and purified betaine sources.

The uptake of betaine is generally linked to two kinds of transport systems; amino acid transport system A (Petronini et al. 1994) and betaine- $\gamma$ amino butyric acid transporter (BGT-1; Petronini et al. 2000). In terms of the intestinal tissue of broiler chicks, Kettunen et al. (2001b) showed that an $\mathrm{Na}^{+}$-dependent and an $\mathrm{Na}^{+}$-independent component are involved. With respect to the $\mathrm{Na}^{+}$-dependent transport, the absorption rate of betaine in broiler chicks increases following supplementation of betaine to the diet (Kettunen et al. 2001b). There is, however, some evidence that the absorption rate of betaine is dose-dependent. Two different levels of betaine were duodenally infused in calves (Puchala et al. 1998). The lower infusion level was associated with a higher intestinal absorption capacity as indicated by an enhanced intestinal muscle-cell activity, whereas at the higher level a decrease of the intestinal muscle-cell activity was observed.

\section{Betaine and nutrient digestibility}

The osmolytic property of betaine supports intestinal cell growth and survival and enhances cell activity, thereby potentially influencing nutrient digestibility. In weaned pigs, the total digestibility of DM and crude protein was improved 
Table 2. The effect of betaine on performance criteria in pigs and poultry

\begin{tabular}{|c|c|c|c|}
\hline Animal & Betaine supplementation (\%) & Betaine effects & Reference \\
\hline \multicolumn{4}{|l|}{ Pigs } \\
\hline Barrows, gilts; 83-116 kg & $0.13-0.5$ & - & Cera \& Schinckel (1995) \\
\hline Pigs; $56-113 \mathrm{~kg}$ & 0.11 & $\uparrow$ & Cromwell et al. (1999) \\
\hline Pigs; $24-111 \mathrm{~kg}$ & $0 \cdot 11$ & - & Cromwell et al. (1999) \\
\hline Grower pigs & 0.1 & $\uparrow 13.3 \%$ & Feng \& Yu (2001) \\
\hline Finisher pigs & 0.1 & $\uparrow 5.7 \%$ & Feng \& Yu (2001) \\
\hline Barrows; 36-64 kg & $0.13-0.5$ & - & Fernandez-Figares et al. (2002) \\
\hline Barrows; $>45 \mathrm{~kg}$ & 0.13 & - & Kitt et al. (1999) \\
\hline Weaned pigs & $0 \cdot 1$ & - & LeMieux et al. (1996) \\
\hline Barrows, gilts; 70-115 kg & $0.13-0.5$ & - & Matthews et al. (2001c) \\
\hline Barrows; 50-110 kg & 0.25 & - & Matthews et al. (2001b) \\
\hline Gilts; $55-110 \mathrm{~kg}$ & 0.13 & - & Matthews et al. (1998) \\
\hline Grower-finisher pigs; > 20 kg & 1.5 & - & Overland et al. (1999) \\
\hline Pigs; $>30 \mathrm{~kg}$ & $0.02-0.1$ & $\uparrow$ & Siljander-Rasi et al. (2003) \\
\hline Grower-finisher pigs; > 34 kg & 0.1 & - & Smith et al. (1994) \\
\hline Gilts; $60-104 \mathrm{~kg}$ & 0.1 & $\uparrow$ & Smith et al. (1995) \\
\hline Pigs; $30-112$ kg & 0.2 & - & Urbanczyk et al. (1999) \\
\hline Barrows, gilts & 0.2 & $\uparrow 7 \% *$ & Urbanczyk (1997) \\
\hline Barrows, gilts & 0.2 & - & Urbanczyk (1997) \\
\hline Pigs; $30-112 \mathrm{~kg}$ & 0.2 & - & Urbanczyk et al. (2000) \\
\hline Weaned pigs & 0.15 & - & van Lunen \& Simmins (2000) \\
\hline Barrows; $20-65 \mathrm{~kg}$ & 0.15 & $\uparrow 10.3 \%$ & Wang \& Xu (1999) \\
\hline Gilts; $20-65 \mathrm{~kg}$ & 0.15 & $\uparrow 15.6 \%$ & Wang \& Xu (1999) \\
\hline Barrows, gilts; $83-118 \mathrm{~kg}$ & $0 \cdot 13$ & - & Webel et al. (1995) \\
\hline Pigs & $0 \cdot 1$ & $\uparrow 13.2 \%$ & Xu et al. (1999a) \\
\hline Piglets & 0.06 & $\uparrow 11.7 \%$ & Xu et al. (1999c) \\
\hline \multicolumn{4}{|l|}{ Poultry } \\
\hline Broiler & 0.65 & $\uparrow \mathrm{ADG} \dagger$ & Garcia et al. (2000) \\
\hline Broiler; male & 0.04 & $-A D G$ & Schutte et al. (1997) \\
\hline Broiler & $0.05-0.15$ & $\uparrow \mathrm{ADG}$ & Virtanen \& Rosi (1995) \\
\hline Grower meat duck & $0.05-0.2$ & $\uparrow \mathrm{ADG}$ & Wang (2000) \\
\hline Finisher meat duck & $0.08-0.1$ & $\uparrow \mathrm{ADG}$ & Wang (2000) \\
\hline Laying hen & 0.01 & $\uparrow$ Egg production & Yalcin et al. (1992) \\
\hline Laying hen; 20 weeks & 0.06 & $\uparrow$ Laying performance, $8.7 \%$ & Zou \& Lu (2002) \\
\hline Laying hen & 0.08 & $\uparrow$ Laying performance & Zou et al. (1998) \\
\hline
\end{tabular}

-, No effect; $\uparrow$, significant increase relative to control (no betaine supplementation); ADG, average daily gain.

* Second half of fattening period.

† Low-energy diet.

by 4.2 and $6.4 \%$, respectively, when betaine was added to the diet (Xu \& Yu, 2000). In coccidian-challenged broilers, betaine improved the digestibility of methionine (Augustine \& Danforth, 1999), protein, lysine, fat and carotenoid (Remus et al. 1995). In addition, intestinal cell activity increases as indicated by a $52 \%$ higher activity of proteolytic enzymes in weaned pigs following dietary supplementation of betaine (Xu \& Yu, 2000).

Overland et al. (1999) reported improved crude fat digestibilities in pigs following dietary supplementation with trimethylamine oxide $\left(\left(\mathrm{CH}_{3}\right)_{3} \mathrm{NO}\right)$, a bacterial metabolite of betaine. This substance is structured similar to betaine with the exception that the glycine in the molecule is replaced by oxygen. However, negative effects of trimethylamine have also been reported such as fish taint (for example, Zentek, 2002). We have also shown (M Eklund, J Wamatu, M Tafaj and R Mosenthin, unpublished results) improved fat digestibility due to betaine supplementation. In this study with weaned pigs, betaine supplementation of a methionine- and cholinedeficient diet increased the total tract digestibility of crude fat by $6.6 \%$. According to Overland et al. (1999), improvements in fat digestibility could be attributed to an increased bile volume due to enhanced bile secretion. In addition, the bile-salt conjugates required for fat digestion consist mainly of glycine (for example, Souffrant, 1991). Since betaine is metabolised to glycine, supplemental betaine might improve fat digestibility as well. It has to be recognised that betaine, with respect to its methyl donor function, is involved in the synthesis of the chylomicrons (Sparks \& Sparks, 1994; Yao \& McLeod, 1994) which are involved in the absorption of fat. Therefore, positive effects of betaine on fat digestibility may be related to the methyl groups supplied by betaine.

Transepithelial electrophysiological studies suggest that betaine changes the transport of ions in the intestinal epithelium of pigs (Kettunen et al. 2001a). Since betaine uptake is in part characterised as an $\mathrm{Na}^{+}$-dependent co-transport (Kettunen et al. 2001b), supplemental dietary betaine might result in higher absorption rates of $\mathrm{Na}^{+}$and $\mathrm{Na}^{+}$-dependent ions. Our own unpublished results (M Eklund, J Wamatu, $\mathrm{M}$ Tafaj and $\mathrm{R}$ Mosenthin, unpublished results) confirm that dietary betaine has a positive effect on the absorption of minerals in weaned pigs.

In ruminants, dietary supplementation with betaine-rich sugarbeet by-products resulted in improved microbial fermentation of the neutral-detergent fibre fraction, which is reflected in an enhanced ruminal production of volatile fatty acids (Wiedmeier et al. 1992). Similarly, the degree of fermentation in the digestive tract of single-stomached 
Potential functions of betaine in livestock

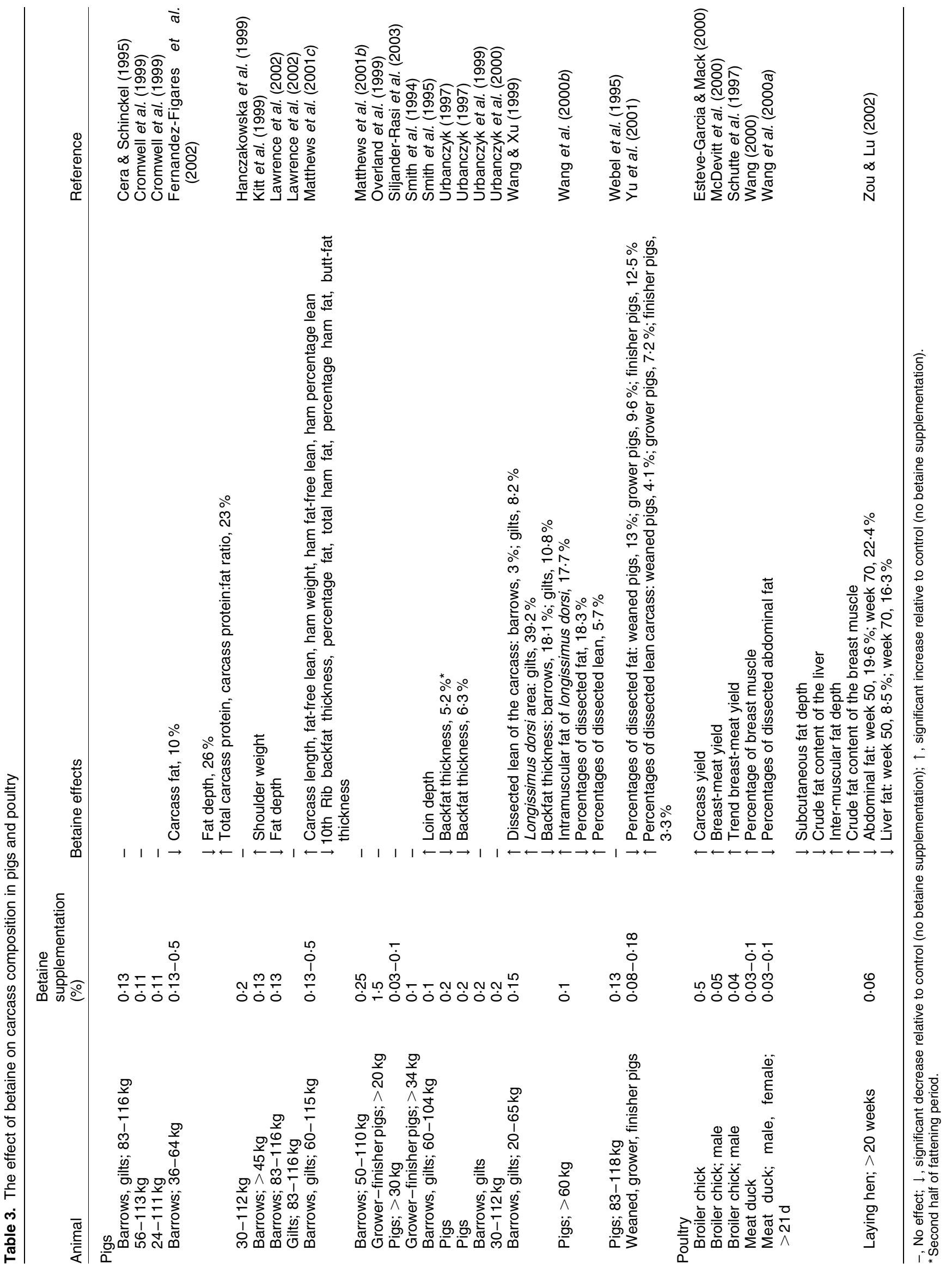




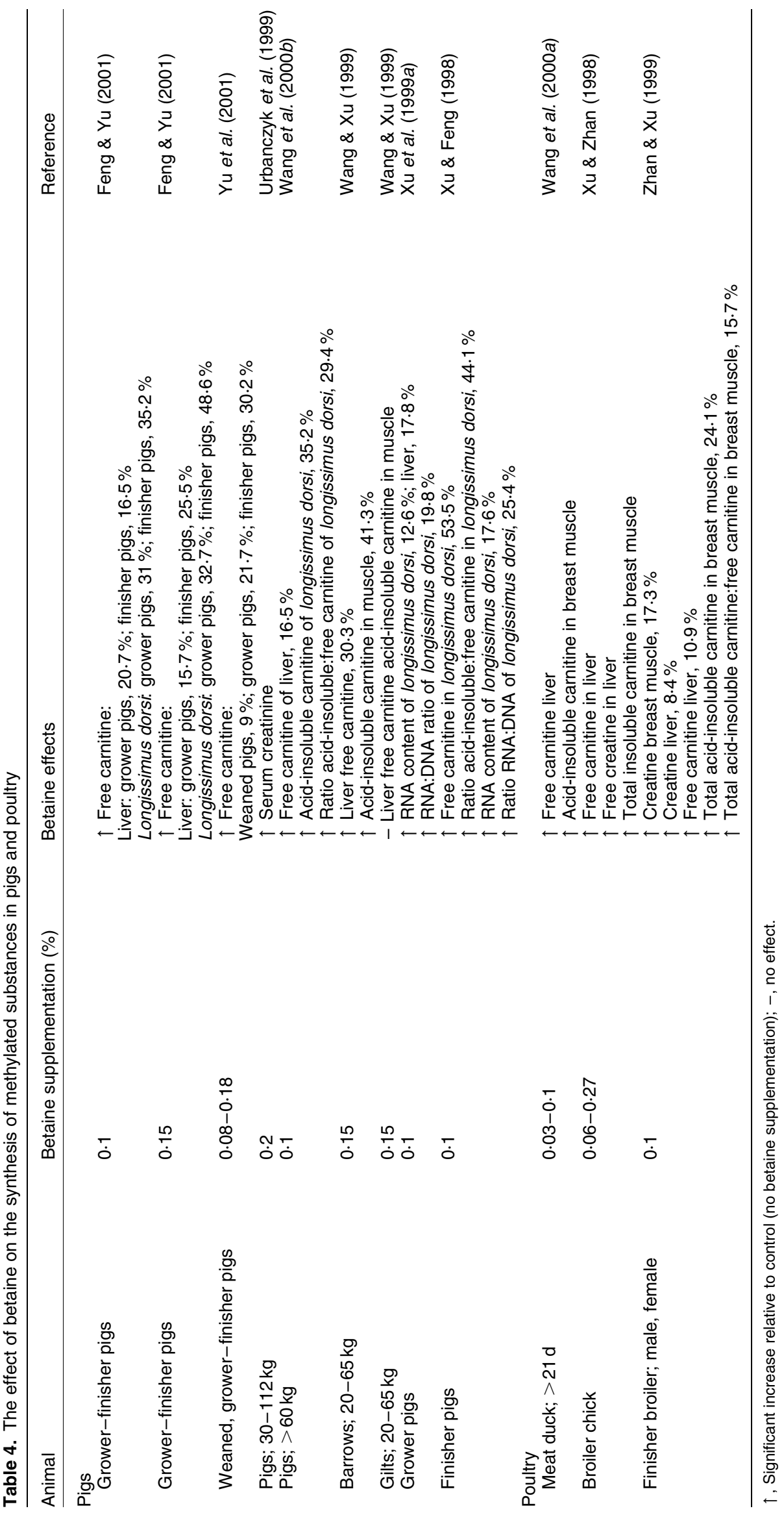


Potential functions of betaine in livestock

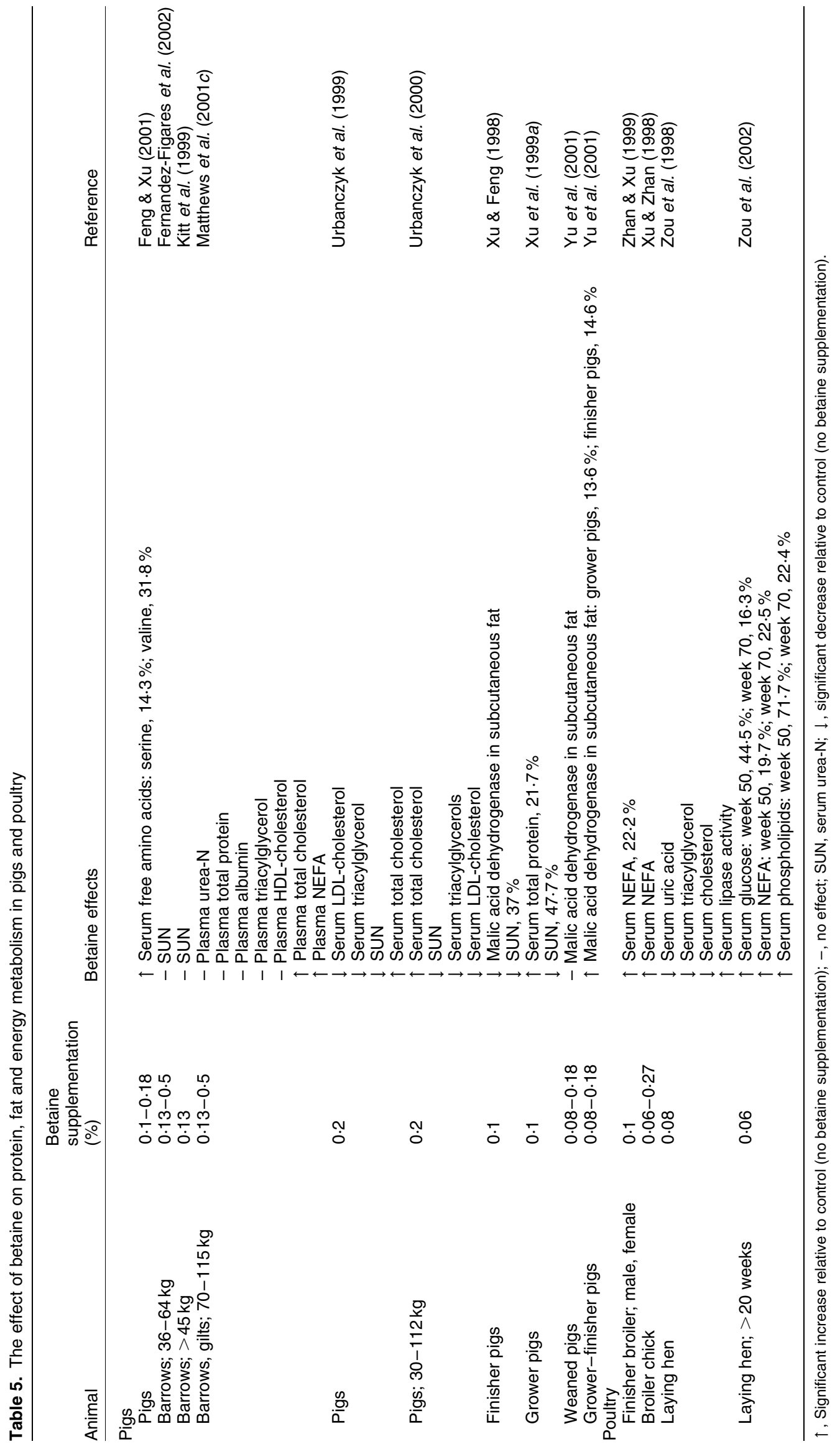




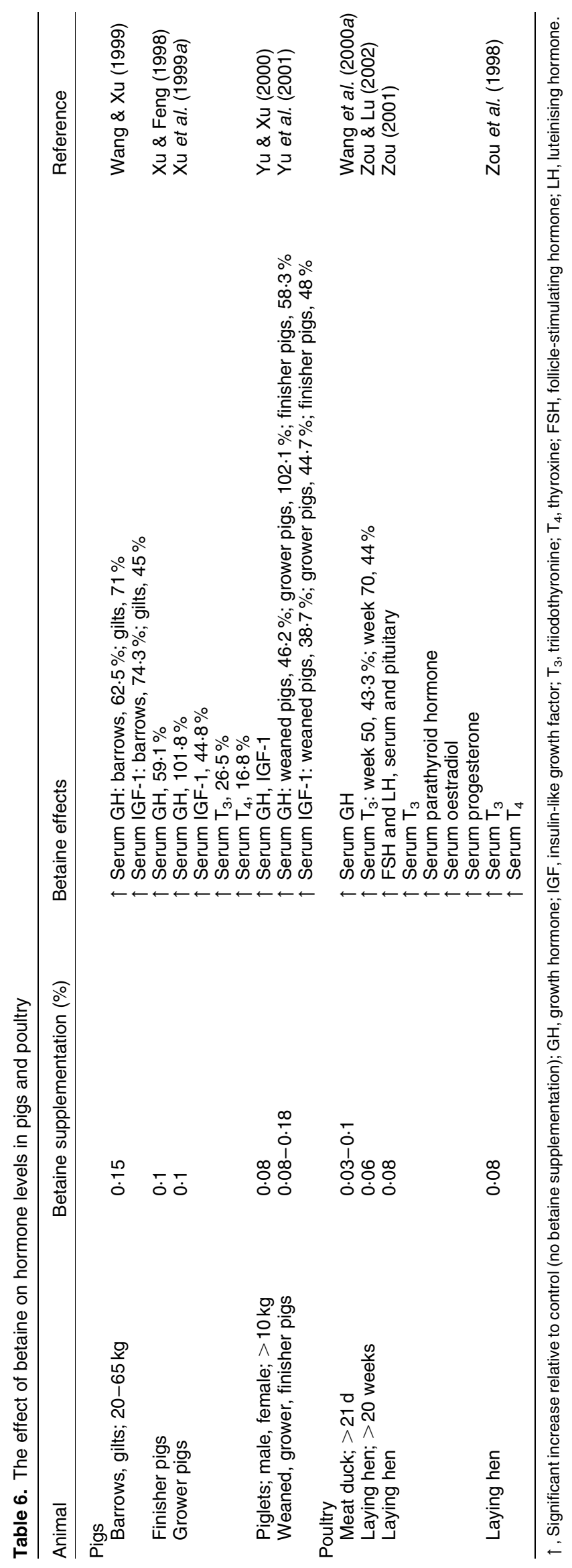


Table 7. The effect of betaine on feed conversion in pigs and poultry

\begin{tabular}{|c|c|c|c|}
\hline Animal & Betaine supplementation (\%) & Betaine effects on feed conversion & Reference \\
\hline \multicolumn{4}{|l|}{ Pigs } \\
\hline Barrows; 83-116 kg & $0 \cdot 13$ & - & Cera \& Schinckel (1995) \\
\hline Barrows, gilts; 83-116 kg & 0.13 & $\downarrow$ & Cera \& Schinckel (1995) \\
\hline Pigs; $56-113 \mathrm{~kg}$ & 0.11 & $\downarrow$ & Cromwell et al. (1999) \\
\hline Pigs; $24-111 \mathrm{~kg}$ & 0.11 & - & Cromwell et al. (1999) \\
\hline Barrows; $>45 \mathrm{~kg}$ & 0.13 & - & Kitt et al. (1999) \\
\hline Barrows; 50-110 kg & 0.25 & - & Matthews et al. (2001b) \\
\hline Pigs; $>30 \mathrm{~kg}$ & $0.03-0.1$ & $\downarrow$ & Siljander-Rasi et al. (2003) \\
\hline Grower-finisher pigs; > 34 kg & $0 \cdot 1$ & - & Smith et al. (1994) \\
\hline Pigs & $0 \cdot 2$ & - & Urbanczyk et al. (1999) \\
\hline Pigs; $30-112$ kg & $0 \cdot 2$ & - & Urbanczyk et al. (2000) \\
\hline Barrows; 83-118 kg & 0.13 & - & Webel et al. (1995) \\
\hline Piglets & 0.06 & $\downarrow 2.2 \%$ & Xu et al. $(1999 c)$ \\
\hline Pigs & 0.1 & $\downarrow 7.9 \%$ & Xu et al. (1999a) \\
\hline Piglets; male, female; >10 kg & 0.08 & $\downarrow 2.8 \%$ & Yu \& Xu (2000) \\
\hline \multicolumn{4}{|l|}{ Poultry } \\
\hline Broiler chick & 0.65 & $\downarrow f: g^{\star}$ & Garcia et al. (2000) \\
\hline Broiler chick & 0.04 & - & Schutte et al. (1997) \\
\hline Finisher meat duck & 0.1 & $\downarrow f: g$ & Wang (2000) \\
\hline Laying hen & 0.01 & $\downarrow$ Feed:egg ratio, 3.8\% & Yalcin et al. (1992) \\
\hline Laying hen; $>20$ weeks & 0.06 & $\downarrow$ Feed:egg ratio, $9 \%$ & Zou \& Lu (2002) \\
\hline Laying hen & 0.08 & $\downarrow$ Feed:egg ratio & Zou et al. (1998) \\
\hline
\end{tabular}

-, No effect; $\downarrow$, significant decrease relative to control (no betaine supplementation); f:g, feed:gain ratio.

* In birds fed the low-protein diet.

animals seems to be affected by dietary betaine supplementation. In broiler chicks, intestinal lactic acid and volatile fatty acid production were enhanced (Kettunen et al. 1999). Changes in bacterial fermentation activity in the gut due to dietary betaine supplementation are supported by our own unpublished results (M Eklund, J Wamatu, M Tafaj and $\mathrm{R}$ Mosenthin, unpublished results). The addition of betaine to a methyl group-deficient diet for weaned pigs improved crude fibre digestibility by $7 \%$. Alterations in microbial fermentation activity could be due to betaine-induced reductions of the osmolality in the digestive tract, as determined in the duodenum of chicks (Klasing et al. 2002).

Improved nutrient digestibility could also be the result of a betaine-induced increase in the contractile activity of the duodenal smooth muscle cells (Puchala et al. 1998). This increase is associated with enhanced pancreatic secretion and digesta mixing. However, the influence of betaine on intestinal muscle cell activity seems to be dose-dependent with higher levels reducing muscle-cell activity, thus possibly decreasing the absorption capacity of the duodenum (Puchala et al. 1998).

\section{Osmotic capacity of betaine in the muscle tissue}

The effect of betaine as an osmolyte is not exclusively restricted to the gut. For example, in kidney cells of rabbits betaine is used to compensate for the osmotic stress caused by electrolytes and urea (Yancey \& Burg, 1989) and in the liver betaine is a potent protectant against bile acid-induced apoptosis (Graf et al. 2002). Additionally, it has been shown that betaine accumulates in muscle cells of pigs (Matthews et al. 2001c), thus possibly affecting meat quality. Alterations in the water-retention capacity of the muscle tissue following dietary betaine supplementation may increase total body weight and carcass weight as well (Esteve-Garcia \& Mack, 2000). Enhanced water-retention capacity can be due to different mechanisms. Increased water retention may be attributed to the osmolytic capacity of the accumulated betaine. Furthermore, increased mineral absorption and retention following dietary supplementation of betaine may also contribute to an increased waterretention capacity of the muscle tissue (Esteve-Garcia \& Mack, 2000). However, a higher body water content may also be explained by an increase in body lean:fat ratio.

Some studies suggest a close relationship between the $\mathrm{pH}$ of meat and supplemental dietary betaine. The initial $\mathrm{pH}$ of the meat was increased in pigs, in association with a decreased drip loss of the meat, when betaine was supplemented to the diet (Matthews et al. 2001c). The pH decline of the meat after slaughtering is induced by lactic acid accumulation. The slower decline in $\mathrm{pH}$ induced by betaine supplementation might be attributed to a reduced lactic acid accumulation, thus affecting meat quality. The retarded decline in $\mathrm{pH}$ results in reduced protein denaturation which, in turn, decreases the water loss of the meat (Matthews et al. 2001c). It has also been shown that dietary betaine reduces lactic acid accumulation in the muscle tissue of horses (Warren et al. 1999). Additionally, betaine may potentially influence meat quality by attenuating $\mathrm{pH}$ induced enzyme inactivation in the meat. Finally, betaine may affect the $\mathrm{pH}$ of the meat via its promoting effect on muscle creatine content (for example, Zhan \& Xu, 1999). Creatine maintains phosphate within the muscle cells which results in a higher buffer capacity in the cells, thereby retarding the post mortem $\mathrm{pH}$ drop caused by accumulation of lactic acid (Pettigrew \& Esnaola, 2001).

\section{Betaine as a methyl donor \\ Methyl group metabolism}

The fundamental principles of methyl group metabolism have been published in several reviews (for example, Snoswell \& Xue, 1987; Kidd et al. 1997; Simon, 1999). Fig. 2 
provides an overview of methyl group metabolism. Methyl groups are required for the synthesis of numerous substances such as creatine, phosphatidylcholine, carnitine, adrenaline, methyl purines as well as methylated amino acids. The methyl group transfer is achieved by the activation of methionine as a methyl donor to S-adenosyl methionine (SAM). This activation enables the transfer of the methyl group from methionine to a methyl group acceptor. In this reaction, SAM is degraded to S-adenosyl homocysteine and subsequently to homocysteine (HC) which is involved in two different metabolic pathways. Firstly, HC can be irreversibly transformed to cysteine which, in turn, can be utilised for protein synthesis. Secondly, it can be re-methylated by other methyl sources to form methionine. The re-methylation to methionine is achieved by two different enzymes: betainehomocysteine-methyltransferase (BHMT; EC 2.1.1.5) or tetrahydrofolate-methyltransferase (THFMT; EC 2.1.1.13). BHMT specifically catalyses the transport of the preformed labile methyl group from the betaine molecule to HC. Betaine commonly originates from the oxidation of choline, but dietary betaine can be used as a methyl donor as well. The methyl group transfer results in the transformation of betaine to dimethylglycine which still contains two methyl groups. These methyl groups can be split off through oxidation in the form of one-carbon fragments. During this reaction dimethylglycine is degraded to sarcosine and finally to glycine. The one-carbon fragments from dimethylglycine as well as from other sources such as formic acid or carboxyl groups of other organic acids are used to synthesise methyl groups de novo via the tetrahydrofolate pathway. The onecarbon fragments bind to the tetrahydrofolate molecule and are transferred via the enzyme THFMT to HC.

\section{Regulation of the transmethylation cycle}

In metabolic reactions, protein synthesis and the formation of SAM compete for the available methionine. Thus, the metabolite $\mathrm{HC}$ has to be distributed between two competing pathways (Finkelstein \& Martin, 1984). Under nonphysiological conditions, such as deficiency of either methyl donors or acceptors, the accumulation of methionine and HC is thought to be toxic to cells (Hafez et al. 1978). Therefore, regulation of the transmethylation cycle is required to maintain physiological levels of $\mathrm{HC}$ and methionine (Finkelstein, 1998). Generally, methionineconserving and methionine-catabolising enzymes are involved. To allow the distribution of $\mathrm{HC}$ during the pathways two mechanisms are suggested: (1) low HC levels induce the transmethylation pathway since the enzymes involved in the transmethylation process show high affinity to HC. If the capacity of these enzymes is reached the transsulfuration pathway is favoured in which SAM acts as a switch. (2) High SAM levels as a consequence of high dietary methionine levels facilitate the trans-sulfuration pathway and limit HC re-methylation by inhibition of the methylating enzymes and by activation of the transsulfuration pathway. In contrast, low HC levels promote the conservation of HC. In addition, glycine seems to have a

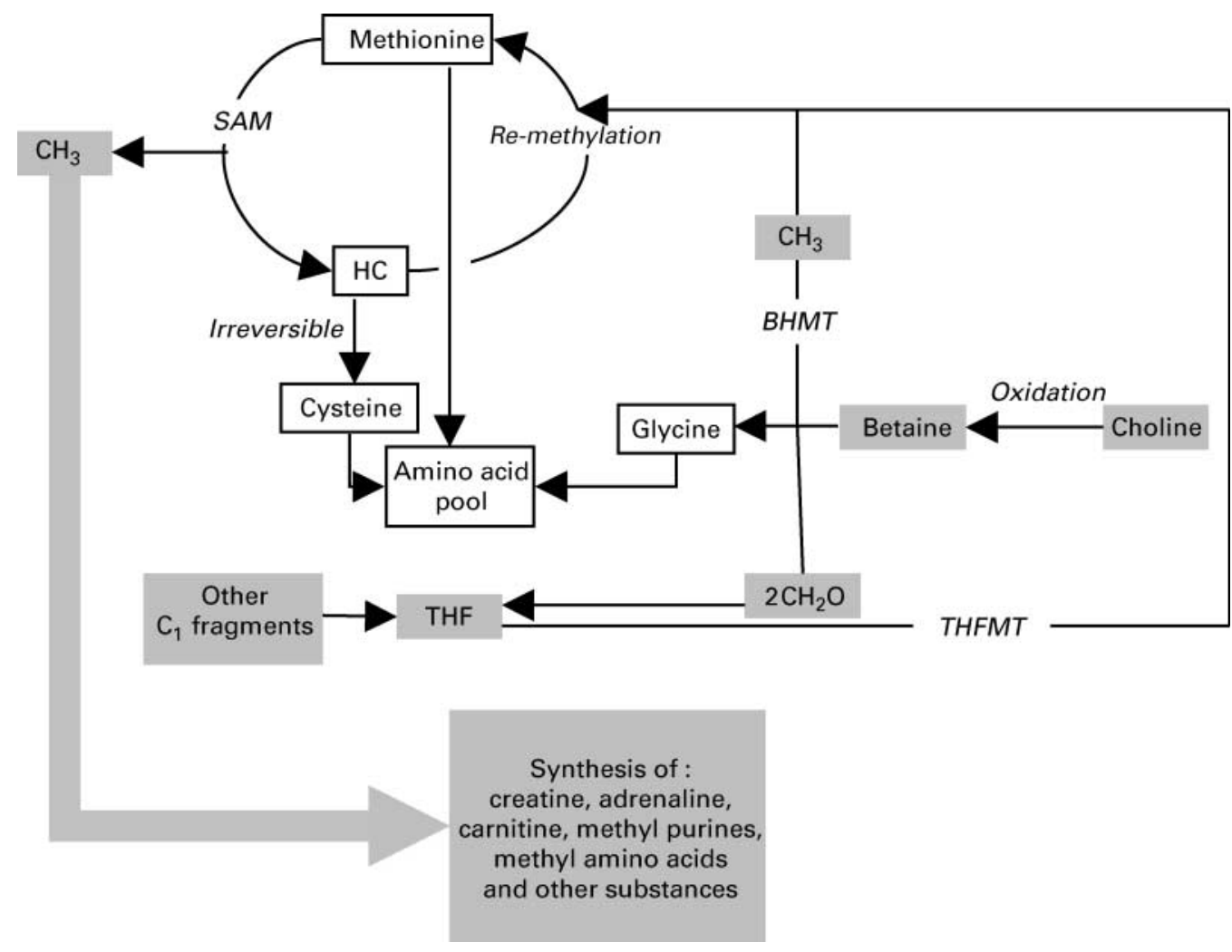

Fig. 2. Methyl group $\left(\mathrm{CH}_{3}\right)$ metabolism. SAM, S-adenosyl methionine; HC, homocysteine; BHMT, betaine-homocysteine-methyltransferase; THF, tetrahydrofolate; $\mathrm{CH}_{2} \mathrm{O}$, formaldehyde group. 
fundamental role in maintaining balance in the transmethylation cycle (Rowling et al. 2002). If methyl acceptors are in short supply, the methyl groups of SAM are transferred to glycine. The involved enzyme shows high affinity, the products are non-toxic and the methyl groups can be regenerated if they are required afterwards.

Changes of SAM and HC levels as well as BHMT activity in plasma as a result of methyl group supply are highly dependent on the actual balance in the transmethylation cycle (Emmert et al. 1996, 1998). According to Emmert et al. (1996), methionine-deficient diets will cause an increase in BHMT activity in poultry. A further increase of BHMT activity in pigs and poultry is observed when methionine-deficient diets are supplemented with choline or betaine (Emmert et al. 1996, 1998). The highest increase was reported when the diet was simultaneously supplemented with cystine. These results indicate that at high concentrations of cystine the methylation pathway is the only possibility to eliminate HC. An increase in BHMT activity has been observed in pigs (for example, Emmert et al. 1998) and poultry (for example, Emmert et al. 1996) when betaine was added to the diets. However, the plasma levels of HC in calves (Puchala et al. 1998) and SAM in the liver of broiler chicks (Kettunen et al. 2001c) were not affected. Thus, it can be assumed that the supplementation of betaine enhances the recycling rate of $\mathrm{HC}$ through higher BHMT activities, thereby maintaining SAM and HC at constant levels. However, these conclusions must not be generalised since Schwab et al. (2002) showed that dietary betaine reduces plasma $\mathrm{HC}$ levels in human subjects. Even so, it has to be considered that methyl donors in excess could interfere with the balance of the transmethylation cycle as supported by animal performance data. Southern et al. (1986) showed that, in pigs, excessive dietary choline has a negative effect on growth performance. This growth depression might be explained by a deficiency in methyl acceptors (Steinmetzer, 1972).

\section{Betaine as a functional substitute for methionine and choline}

The main function of methionine with regard to the transmethylation cycle is the transfer of the methyl groups from different origins to the acceptor molecules. However, methionine is also required for protein synthesis, since it is an essential amino acid and a precursor of cysteine. Choline, a betaine precursor, is also essentially required for a number of physiological functions such as membrane synthesis or formation of acetylcholine. In addition, it can be assumed that choline oxidation may be a rate-limiting step in the synthesis of betaine, since the addition of choline to diets for pigs was not as efficient as the addition of dietary betaine (Siljander-Rasi et al. 2003). Choline and methionine are both used as feed additives in livestock nutrition. Thus, besides the function of betaine as a methyl donor, there is economic interest in reducing the dietary supply of choline and methionine by adding betaine to the diet in order to meet the animal's methyl group requirement. In addition, the supplementation of betaine might enhance methionine and choline availability.
Numerous investigations have been carried out to evaluate the effect of dietary betaine supplementation on animal performance. These studies have focused on the effect of betaine as a substitute for methionine and choline. Additionally, some interest was directed to the function of supplemental betaine in methyl donor-adequate diets.

It is generally accepted that diets for ruminants supply low levels of methyl donors because dietary choline (Neill et al. 1979; Dawson et al. 1981) and betaine (Mitchell et al. 1979) are degraded by ruminal microbes. The use of either protected choline in calves (Gralak et al. 1998) or lipidcoated betaine as feed additives in methionine-deficient diets for heifers (Löest et al. 2001) did not affect weight gain or feed conversion. Since the results of a feeding trial with lambs showed that betaine can positively improve animal performance (Fernadez et al. 1998), more attention should be directed to the degradation characteristics of betaine in the rumen. In lactating ewes, which are known to secrete considerable amounts of methyl compounds such as choline, creatinine and carnitine into the milk, it has been shown that during lactation, the activity of THFMT is enhanced but not the activity of BHMT (Xue \& Snoswell, 1985b). Snoswell \& Xue (1987) concluded that due to the limited supply of methyl donors to ruminants, the THFMT pathway rather than the BHMT pathway is of physiological importance. Thus, in ruminants there seems to be no basic requirement for preformed labile methyl groups as provided by the betaine molecule. Since sheep exhibit BHMT activity in response to betaine administration (Xue \& Snoswell, 1985a), it remains open whether metabolically available betaine in ruminants will improve animal performance.

In pigs (for example, Emmert et al. 1998; Wang et al. $2000 \mathrm{~b}$ ) and poultry (for example, Xu \& Zhan, 1998; Wang, 2000), it has been shown that following betaine supplementation, the activity of BHMT increases, indicating that these species have a specific requirement for preformed labile methyl groups. Pigs (Emmert et al. 1998), in general, show higher BHMT levels compared with other species (Sidransky \& Farber, 1960). Therefore, it can be assumed that pigs are highly dependent on the supply of the preformed labile methyl groups as provided by the betaine molecule. However, in contrast with the results obtained in poultry (for example, Sakomura et al. 1996), betaine apparently cannot replace methionine or choline in diets for pigs (for example, Alaviuhkola \& Suomi, 1990; Matthews et al. 2001a). The lack of response in pigs compared with the results in poultry may be attributed to considerable differences in the choline requirement between pigs (0.3-0.6 g/kg; National Research Council, 1998), and poultry (0.75-1.3 g/kg; National Research Council, 1994). Secondly, the requirement for cystine is higher in poultry compared with pigs, thereby possibly enhancing the transsulfuration pathway and indirectly increasing the methylation rates. Based on the values for choline requirement in pigs it is obvious that feed ingredients provide sufficient choline. However, total choline content may not always represent the amount of choline which is available for oxidation to betaine since most of the choline is bound to phospholipids. 


\section{Efficacy of methionine replacement by betaine}

Pesti et al. (1979) showed that the dietary addition of betaine and methionine can replace each other in broiler chicks. Florou-Paneri et al. (1997) showed that between 30 and $80 \%$ of the supplemental methionine can be substituted by betaine without negative effects on performance. According to Garcia et al. (1999), however, the bioavailability of betaine is only 50-67\% compared with methionine based on daily gain and feed conversion. Virtanen \& Rosi (1995) reported that growth performance and feed efficiency in broiler chicks were linear in response to methionine and betaine supplementation. In these studies, betaine was twice as efficient as methionine. According to the results of several other studies, betaine and methionine cannot replace each other (for example, Schutte et al. 1997; McDevitt et al. 2000). The extent to which methionine can be substituted by betaine may depend on the dietary supply of cystine as well. Methionine will be exclusively used for protein synthesis when the animal's cystine requirement is met. Otherwise, part of the methionine will be irreversibly degraded to cysteine. Interactions between betaine and cystine supplementation are confirmed by the results of Firman \& Remus (1999), who showed that the combination of dietary cystine and betaine had a positive impact on feed conversion in broiler chicks compared with these additives fed alone.

\section{Efficacy of choline replacement by betaine}

Estimates for choline requirement in poultry reveal that $25 \%$ may be supplied as betaine (Lowry et al. 1987). Stekol et al. (1953) even showed that choline is relatively inefficient in the methylation of $\mathrm{HC}$ and creatine in broilers when compared with betaine, which was also confirmed in pigs (Siljander-Rasi et al. 2003). A higher efficacy of betaine in poultry as compared with pigs may partly be attributed to the use of ionophore coccidiostats in poultry diets which inhibit the activity of choline oxidase (Tyler, 1977), and, therefore, additional betaine might be required for an adequate supply of labile methyl groups.

\section{Betaine supplementation to methyl group-adequate diets}

\section{Animal performance and carcass quality}

Following the intraduodenal infusion of betaine, concentrations of plasma methionine, cystine and glycine increased in calves (Puchala et al. 1998) and small ruminants (Puchala et al. 1995); however, cystine levels were not affected in small ruminants. The increase in glycine concentration reveals that complete de-methylation of betaine occurs which makes methyl groups available for metabolic functions. Since plasma methionine and cystine concentrations are also enhanced, higher availabilities of sulfurous amino acids can be assumed. For example, enhanced feather growth in poultry following betaine supplementation confirms the improvement in sulfur amino acid availability (Garcia et al. 2000). Since methionine and cystine are essentially required for protein synthesis, the feeding of methionine-deficient diets results in growth depression. Consequently, any improvement in the availability of sulfur amino acids due to betaine supplementation to the diet will have a positive effect on growth performance. The addition of betaine to methyl donor-adequate diets improves weight gain in poultry (for example, Virtanen \& Rosi, 1995; Wang, 2000) and pigs (for example, Wang \& Xu, 1999; Feng \& Yu, 2001), though the results of several other studies reveal no effect of supplemental betaine on animal performance (Table 2). Additionally, results from different studies in pigs, poultry (Table 3) and lambs (Fernandez et al. 2000) indicate considerable changes in carcass composition. Due to reductions in carcass fat content and higher percentages of lean carcass, betaine is often referred to as a "carcass modifier'. In poultry, reductions in abdominal fat were obtained (for example, McDevitt et al. 2000; Wang, 2000) and breast-muscle yield was enhanced (for example, Firman \& Remus, 1999) (Table 3). In pigs, carcass fat content was reduced by as much as 10 to $18 \%$ (Wang et al. 2000b; Fernandez-Figares et al. 2002) (Table 3). Additionally, there was an increase in the lean content of the carcass ranging between 4 and $8 \%$ (for example, Wang \& Xu, 1999; Yu et al. 2001). The reduction of total carcass fat content is reflected by reductions in backfat thickness in pigs (for example, Wang \& Xu, 1999; Matthews et al. 2001c). Increases in carcass leanness can be attributed to an increase in carcass length (Matthews et al. 2001a) and greater loin depth in pigs (for example, Cera \& Schinckel, 1995) (Table 3).

Some authors explain the mode of action of betaine as a 'carcass modifier' with the methyl donor capacity of betaine. The improvement of carcass lean percentage can be attributed to the higher availability of methionine and cystine for protein deposition in betaine-supplemented diets (McDevitt et al. 2000). The consequent improvement in utilisation of dietary amino acids for protein synthesis would leave less amino acids for deamination and eventual synthesis of adipose tissue (Wallis, 1999). Additionally, it has been shown that betaine supplementation enhances the synthesis of methylated compounds such as carnitine. In broiler chicks (for example, Xu \& Zhan, 1998) and pigs (for example, Yu et al. 2001), carnitine concentrations in liver and muscle are increased from $9 \%$ up to $53 \%$ (Table 4). Carnitine is required for the transport of fatty acids through the inner mitochondrial membrane where fatty acid oxidation takes place (Stryer, 1988). Dietary carnitine addition has been shown to reduce carcass and liver lipid content in pigs (for example, Owen et al. 1996). Thus, provided that supplementation of betaine enhances carnitine synthesis, betaine may have a positive effect on the reduction of carcass fat content as well. Moreover, the synthesis and secretion of phosphatidylcholine and apo B are limiting factors in the synthesis of VLDL and chylomicrons (Sparks \& Sparks, 1994; Yao \& McLeod, 1994). VLDL prevents the deposition of fat in the liver and accelerates the removal of fat from the liver (Yao \& Vance, 1990). Dietary betaine has been shown to support the synthesis of phosphatidylcholine from phosphatidylethanolamine and may therefore affect liver fat metabolism (Yao \& Vance, 1989). Additionally, betaine may improve choline availability, thus providing more choline for the synthesis of VLDL. There is also growing evidence that BHMT enhances the synthesis of apo B in liver cells due to methyl group supply (Sowden et al. 1999). Alterations of fat 
metabolism following betaine supplementation are supported by the results obtained in several studies with poultry and pigs (Table 5). In laying hens, lipase activity was enhanced and a decrease in the concentration of triacylglycerols and cholesterol in serum was observed (for example, Zou et al. 1998). In broiler chicks, the level of NEFA in serum is increased (Xu \& Zhan, 1998). Interestingly, the intramuscular fat content is not negatively affected (Wang et al. 2000b) (Table 4). For example, Kettunen et al. (2001b) showed an increased binding of $60 \%$ of the recovered betaine to the lipid fraction in the liver, which, in turn, indicates interactions with the lipid metabolism. Betaine may have been used for the synthesis of phospholipids or choline. In contrast, labelled betaine was detected in the water phase obtained from breastmuscle tissue suggesting the presence of free betaine or derivatives in muscle cells. Consequently, betaine may not interfere with the intramuscular fat depots.

\section{Interactions of betaine with growth-regulating and metabolic factors}

In a comparative study, Schutte et al. (1997) supplied methionine-adequate diets with either methionine or betaine. The results showed that betaine, but not methionine, improved carcass yield. Thus, the mode of action of betaine as a 'carcass modifier' cannot only be mediated via a methionine-sparing effect but also may reflect direct interactions of betaine and its metabolites with factors involved in the regulation of metabolic pathways affecting growth. In pigs and poultry, it has been shown that supplemented betaine elevates the plasma growth hormone (GH) level between 46 and $102 \%$ (for example, Yu et al. 2001) (Table 6). Furthermore, there was an increase in insulin-like growth factor-1 levels in plasma between 39 and $75 \%$ (Wang \& Xu, 1999; Yu et al. 2001) (Table 6). In human subjects, the infusion of glycine enhances plasma GH levels (Kasai et al. 1980). Glycine is thought to play an important role in the control of the hypothalamic-pituitary function (Kasai et al. 1980). Therefore, it can be assumed that the effect of betaine on GH levels is mediated via its metabolite glycine, based on the fact that betaine is degraded to glycine (Puchala et al. 1998). The alterations of carcass composition in different species following the dietary addition of betaine resemble results obtained after the injection of $\mathrm{GH}$ (for example, Chung et al. 1985; Etherton et al. 1986). Following $\mathrm{GH}$ application, pigs show improvements in weight gain and carcass lean percentage due to a more efficient protein synthesis, while fat deposition is reduced. Interactions of betaine with the hormonal system are also supported by the results of other studies in pigs and poultry (Table 6). According to Zou et al. (1998), Zou (2001) and Zou \& Lu (2002) the dietary supplementation of betaine increases serum levels of several hormones such as luteinising hormone, follicle-stimulating hormone, triiodothyronine, thyroxine, oestradiol and progesterone in laying hens. Though the direct interactions of betaine with these hormones are not completely understood yet, there is some evidence that betaine is linked to triiodothyronine and thyroxine secretions, since thyroidectomy induces an increase in the activity of BHMT (Shibata et al. 2003).
The increase in the concentrations of methylated substances such as carnitine (for example, Feng \& Yu, 2001) and creatine (Xu \& Feng, 1998) in muscle tissue (Zhan \& Xu, 1999) and creatinine in serum samples (Urbanczyk et al. 1999) is often related to the methyl donor capacity of betaine. Increased GH levels due to dietary betaine supplementation will affect the metabolic requirement for these methylated compounds. GH induces fatty acid oxidation resulting in higher carnitine requirement (for example, Goodman et al. 1988). GH may be also involved in the control of the rate of creatine uptake by the muscle tissue (Tan \& Ungar, 1979). Enhanced DNA and RNA methylation rates as observed in the muscle tissue of pigs (Xu \& Feng, 1998) and poultry (Zhan, 2000) may be related to higher muscle-cell synthesis following the increase in GH levels as shown in rats (Flaim et al. 1978). The requirement for the above-mentioned methylated compounds increases during betaine-induced elevations in GH levels. Since the required methyl groups may be provided by the betaine molecule, it can be speculated whether betaine promotes their synthesis simultaneously.

\section{Effects of betaine on energy and nitrogen utilisation}

Improvements in feed conversion ratio ranging between $2 \cdot 8$ and $7.9 \%$ in laying hens (for example, Zou \& Lu, 2002) and pigs (for example, Xu et al. 1999a,c) were reported when betaine was added to the diet (Table 7). This may be explained by a more efficient utilisation of dietary protein for lean accretion which is supported by reduced blood urea$\mathrm{N}$ levels, increased $\mathrm{N}$ retention and reduced requirement for metabolisable energy. Dietary betaine supplementation has been shown to reduce serum or plasma urea-N content in pigs by up to $47 \%$ (for example, Xu et al. 1999a) (Table 5). Blood urea-N levels correlate with the protein turnover rate. According to Coma et al. (1995), $\mathrm{N}$ retention is maximised when urea- $\mathrm{N}$ is minimised. These results indicate that supplemental betaine can reduce protein turnover rate resulting in higher $\mathrm{N}$ retention which, in turn, has a positive effect on carcass leanness. Following the post-ruminal infusion of betaine, steers showed a trend towards an increased $\mathrm{N}$ retention (Löest et al. 1999). These results were confirmed in pigs which showed a trend towards an improved $\mathrm{N}$ utilisation following betaine supplementation of the diet (Webel, 1994). A lower rate of protein breakdown is also reflected by a reduced urinary $\mathrm{N}$ excretion as shown in pigs (Yu \& Xu, 2000).

The energy required for breakdown and re-synthesis of body protein as well as for $\mathrm{N}$ excretion contributes to a great extent to the animal's energy requirement for maintenance. Schrama et al. (2003) and Campbell et al. (1997) showed that the maintenance requirement for energy is reduced in pigs receiving betaine-supplemented diets. Provided that adequate dietary protein is available, a more efficient protein synthesis may be assumed. Otherwise, in contrast with the aforementioned lipotropic properties of betaine, increases in energy retention may enhance fat accretion. Löest et al. (1998) showed that dietary betaine addition may result in higher carcass fatness in steers.

According to Esteve-Garcia et al. (2000) and FernandezFigares et al. (2002) the viscera weight in pigs, and poultry 
in particular, is reduced when betaine is added to the diet. Since these organs are associated with the highest protein turnover rate in the whole body (Blaxter, 1989), reductions in the maintenance requirement for energy may be expected. However, improvements in energy availability can also be due to the osmolytic properties of betaine as described earlier (p. 32).

\section{Factors affecting the efficacy of betaine}

Inconsistency in the effects of betaine on growth performance and carcass composition in relation to the protein and energy content of the diet have been frequently reported and have been related to different factors (for example, Haydon et al. 1995; Matthews et al. 1998; Garcia et al. 2000; Lawrence et al. 2002). Though the addition of betaine improves energy availability, betaine is an $\mathrm{N}$-containing substance which requires energy to be excreted. Consequently, increasing the dietary betaine level may reduce its efficacy. While Fernandez-Figares et al. (2002) showed positive linear relationships between betaine effects and betaine levels, Xu et al. (1999b) reported that the efficiency of supplemental betaine is reduced at dietary levels above $0.08 \%$.

Environmental conditions such as stress modulate the mode of action of betaine. Kitt et al. (1999) showed trends to improved shoulder weight in crowded pigs fed diets supplemented with betaine. However, according to Matthews et al. (2001b), betaine reduces water loss in the meat of normally housed pigs, while water loss is increased in crowded pigs. In normally housed pigs, serum urea- $\mathrm{N}$ is reduced, while in crowded pigs fed diets with supplemental betaine serum urea- $\mathrm{N}$ values were elevated.

Age, sex and genetics influence the capacity for lean accretion and the amount of fat deposition and consequently might interfere with the mode of action of betaine. An important factor for lipotropic agents is the initial degree of fatness of the animal, because lipotropic agents such as betaine should be more efficient in fat animals (Garcia et al. 2000). Barrows, which are associated with higher capacity for fat accretion than gilts, showed $18.1 \%$ reduction in backfat content, while the reduction in gilts was only $10.8 \%$ (Wang \& Xu, 1999). According to Lawrence et al. (2002), dietary betaine supplementation decreased backfat depth in barrows only. In contrast, betaine addition improved feed conversion in gilts but not in barrows (Cera \& Schinckel, 1995). It can be assumed that barrows in general show reduced protein turnover rates compared with gilts and, therefore, betaine is not as efficient in improving lean gain in barrows. The improvement in average daily gain is lower in weaned $(8.7 \%)$ than in grower-finisher $(13.3 \%)$ pigs (Yu et al. 2001). Feed conversion was also more improved in grower-finisher $(7.9 \%$ ) (Xu et al. 1999a) rather than in weaned pigs $(2.2 \%$ ) (Xu et al. 1999c). Due to their intensive growth, weaned pigs show a high capacity for lean accretion and, therefore, betaine can be more efficient in older animals. Also the time factor seems to affect the efficiency of dietary betaine. Schrama et al. (2003) showed that energy retention in pigs improves over time following the supplementation of betaine to the diet. According to Matthews et al. (1998, 2001b), weight gain (Matthews et al.
$2001 b$ ) and feed conversion (Matthews et al. 1998) are only improved during the late finishing period. Betaine may enhance the activity of the pituitary gland as indicated by an increased cAMP content (Zou et al. 2002) and therefore the increase in GH level may be more probably caused by higher synthesis rates of GH than by short-term GH release. Consequently, metabolic responses to betaine may be timedependent as has been shown by Schrama et al. (2003).

\section{Implications}

The osmoprotective properties of betaine may result in an increased proliferation of the intestinal structure which, in turn, may have a positive impact on animal health status and nutrient digestibility. Since the use of in-feed antibiotics will be restricted in the future, there will be growing interest in using betaine as a bioactive compound for improving gut health. Furthermore, betaine seems to contribute to a certain extent to a reduced requirement for methyl donors such as methionine and choline. There is also some evidence that betaine may improve the availabilities of methionine and choline or may interact with metabolic factors regulating growth such as $\mathrm{GH}$ and insulin-like growth factor-1. Additionally, considerable improvements in performance and carcass quality such as improved carcass quality and lower feed conversion have been reported. In particular, under certain physiological conditions, such as sub-optimal protein turnover, exposure to pathogens or osmotic stress, betaine may have a positive impact in livestock production.

\section{References}

Alaviuhkola T \& Suomi K (1990) Effect of betaine supplementation of low methionine diet for growing pigs. Annales Agriculturae Fenniae 29, 127-129.

Alfieri RR, Cavazzoni A, Petronini PG, Bonelli MA, Caccamo AE, Borghetti AF \& Wheeler KP (2002) Compatible osmolytes modulate the responses of porcine endothelial cells to hypertonicity and protect them from apoptosis. Journal of Physiology 540, 499-508.

Augustine PC \& Danforth HD (1999) Influence of betaine and salinomycin on intestinal absorption of methionine and glucose and on the ultrastructure of intestinal cells and parasite developmental stages in chicks infected with Eimeria acervulina. Avian Diseases 43, 89-97.

Augustine PC, McNaughton JL, Virtanen E \& Rosi L (1997) Effects of betaine on the growth performance of chicks inoculated with mixed cultures of avian Eimeria species and on invasion and development of Eimeria tenella and Eimeria acervulina in vitro and in vivo. Poultry Science $\mathbf{7 6}$, 802-809.

Bagnasco S, Balaban R, Fales HM, Yang YM \& Burg M (1986) Predominant osmotically active organic solutes in rat and rabbit renal medullas. Journal of Biological Chemistry 261, 5872-5877.

Bessieres MA, Gibon Y, Lefeuvre JC \& Larher F (1999) A single step purification for glycine betaine determination in plant extracts by isocratic HPLC. Journal of Agricultural and Food Chemistry 47, 3718-3722.

Blaxter K (1989) The minimal metabolism. In Energy Metabolism in Animals and Man, pp. 120-145. Cambridge, MA: Cambridge University Press.

Campbell RG, Morley WC \& Zabaras-Krick B (1997) The effects of betaine on protein and energy metabolism in pigs. In 
Manipulating Pig Production VI, p. 243 [PD Cranwell, editor]. Werribee, Australia: Australian Pig Science Association.

Cera KR \& Schinckel AP (1995) Carcass and performance responses to feeding betaine in pigs. Journal of Animal Science 73, Suppl. 1, 82.

Chambers ST \& Kunin CM (1985) The osmoprotective properties of urine for bacteria: The protective effect of betaine and human urine against low $\mathrm{pH}$ and high concentrations of electrolytes, sugars, and urea. Journal of Infectious Diseases 152, $1308-1316$.

Chendrimada TP, Garcia NM, Pesti GM, Davis AJ \& Bakalli RI (2002) Determination of the betaine content of feed ingredients using high-performance liquid chromatography. Journal of the Science of Food and Agriculture 82, 1556-1563.

Chung CS, Etherton TD \& Wiggins JP (1985) Stimulation of swine growth by porcine growth hormone. Journal of Animal Science 60, $118-130$.

Clarke WC, Virtanen E, Blackburn J \& Higgs D (1994) Effects of a dietary betaine/amino acid additive on growth and seawater adaptation in yearling chinook salmon. Aquaculture 121, $137-145$.

Coma J, Carrion D \& Zimmerman DR (1995) Use of plasma urea nitrogen as a rapid response criterion to determine the lysine requirement of pigs. Journal of Animal Science 73, Suppl. 1, 82.

Cromwell GL, Lindemann MD, Randolph JR, Monegue HJ, Laurent KM \& Parker JR (1999) Efficacy of betaine as a carcass modifier in finishing pigs fed normal and reduced energy diets. Journal of Animal Science 77, Suppl. 1, 179.

Dawson KM \& Baltz JM (1997) Organic osmolytes and embryos: substrates of the Gly and beta transport systems protect mouse zygote against the effects of raised osmolarity. Biology of Reproduction 56, 1550-1558.

Dawson RM, Grime DW \& Lindsay DB (1981) On the insensitivity of sheep to the almost complete microbial destruction of dietary choline before alimentary-tract absorption. Biochemical Journal 196, 499-504.

Emmert JL, Garrow TA \& Baker DH (1996) Hepatic betainehomocysteine methyltransferase activity in the chicken is influenced by dietary intake of sulfur amino acids, choline and betaine. Journal of Nutrition 126, 2050-2058.

Emmert JL, Webel DM, Biehl RR, Griffiths MA, Garrow LS, Garrow TA \& Baker DH (1998) Hepatic and renal betainehomocysteine methyltransferase activity in pigs as affected by dietary intakes of sulfur amino acids, choline, and betaine. Journal of Animal Science 76, 606-610.

Esteve-Garcia E \& Mack S (2000) The effect of DL-methionine and betaine on growth performance and carcass characteristics in broilers. Animal Feed Science and Technology 87, 85-93.

Etherton TD, Wiggins JP, Chung CS, Evock CM, Rebhun JF \& Walton PE (1986) Stimulation of pig growth performance by porcine growth hormone and growth hormone-releasing factor. Journal of Animal Science 63, 1389-1399.

EU-Safety Data Sheet (1999a) Product Name: Betaine Hydrochloride. http://www.aminoactives.com/pdf/eumsds/ BetaineHydrochloride.pdf

EU-Safety Data Sheet (1999b) Product Name: Betaine. http:// www.aminoactives.com/pdf/eumsds/BetaineAnhydrous.pdf

EU-Safety Data Sheet (1999c) Product Name: Betaine Monohydrate. http://www.aminoactives.com/pdf/eumsds/ BetaineMonohydrate.pdf

Feng J \& Xu ZR (2001) Effect of betaine on muscle, liver and serum amino acid composition in finishing swine. Journal of Zhejiang University Agriculture and Life Sciences 27, 107-110.

Feng J \& Yu DY (2001) Effect of betaine on growth performance and methyl transfer function in finisher pigs. Chinese Journal of Animal Science 37, 8-10.
Ferket PR (1995) Flushing syndrome in commercial turkeys during the grow-out stage. In Proceedings of the Smithkline Beecham Pacesetter Conference, National Turkey Federation Annual Meeting, 10 January 1995, pp. 5-14. Nutley, NJ: Smithkline Beecham Animal Health.

Fernandez C, Lopez-Saez A, Gallego L \& de la Fuente JM (2000) Effect of source of betaine on growth performance and carcass traits in lambs. Animal Feed Science and Technology 86, 71-82.

Fernandez C, Gallego L \& Lopez-Bote CJ (1998) Effect of betaine on fat content in growing lambs. Animal Feed Science and Technology 73, 329-338.

Fernandez-Figares I, Wray-Cahen D, Steele NC, Campbell RG, Hall DD, Virtanen E \& Caperna TJ (2002) Effect of dietary betaine on nutrient utilization and partitioning in the young growing feed-restricted pig. Journal of Animal Science 80, 421-428.

Finkelstein JD (1998) The metabolism of homocysteine: pathways and regulation. European Journal of Pediatrics 157, Suppl. 2, S40-S44.

Finkelstein JD \& Martin JJ (1984) Methionine metabolism in mammals. Distribution of homocysteine between competing pathways. Journal of Biological Chemistry 259, 9508-9513.

Firman JD \& Remus JC (1999) Relationship between cystine and betaine in low methionine diets. Poultry Science 78, Suppl. 1, 135.

Flaim KE, Li JB \& Jefferson LS (1978) Protein turnover in rat skeletal muscle: effects of hypophysectomy and growth hormone. American Journal of Nutrition 234, E38-E43.

Florou-Paneri P, Kufidis DC, Vassilopoulos VN \& Spais AV (1997) Performance of broiler chicks fed on low choline and methionine diets supplemented with betaine. Epitheorese Zootehnikes Epistemes 24, 103-111.

Garcia MN, Chendrimada TP, Pesti GM \& Bakalli RI (1999) Relative bioavailability of two labile methyl sources methionine and betaine. Poultry Science 78, Suppl. 1, 135.

Garcia MN, Pesti GM \& Bakalli RI (2000) Influence of dietary protein level on the broiler chicken's response to methionine and betaine supplements. Poultry Science 79, 1478-1484.

Goodman AD, Hoekstra S, Busch RS, Meyer GS \& Abend SS (1988) Effects of prolactin and growth hormone on tissue and serum carnitine in the rat. Endocrinology 123, 1955-1961.

Graf D, Kurz AK, Reinehr R, Fischer R, Kircheis G \& Haussinger D (2002) Prevention of bile acid-induced apoptosis by betaine in rat liver. Hepatology 36, 829-839.

Gralak MA, Lesniewska V, Puchala R, Barej W \& Dymnicki E (1998) The effect of betaine and rumen undegradable choline on growth rate and feed efficiency in calves. Journal of Animal and Feed Sciences 7, 229-233.

Hafez YS, Chavez E, Vohra P \& Kratzer FH (1978) Methionine toxicity in chicks and poults. Poultry Science 57, 699-703.

Hanczakowska E, Urbanczyk J \& Swiatkiewycz M (1999) The efficiency of betaine and organic compounds of chromium in fattening of pigs with ad libitum or restricted feeding. Roczniki Naukowe Zootechniki 26, 263-274.

Haussinger D (1998) Osmoregulation of liver cell function: signalling, osmolytes and cell heterogeneity. Contributions to Nephrology 123, 185-204.

Haydon KD, Campbell RG \& Prince TJ (1995) Effect of dietary betaine additions and amino:calorie ratio on performance and carcass traits of finishing pigs. Journal of Animal Science 73, Suppl. 1, 83 .

Hochachka PW \& Somero GN (1984) Biochemical Adaptation. Princeton, NJ: Princeton University Press.

Kasai K, Suzuki H, Nakamura T, Shiina H \& Shimoda SI (1980) Glycine stimulated growth hormone release in man. Acta Endocrinologica (Copenhagen) 93, 283-286. 
Kettunen H, Peuranen S, Apajalahti J, Jatila H, Nurminen P \& Saarinen M (1999) Effect of betaine on the microbiology of the chicken gastrointestinal tract, p. 186. In Proceedings of the 12th European Symposium of Veldhofen, The Netherlands.

Kettunen H, Peuranen S \& Tiihonen K (2001a) Betaine aids in the osmoregulation of duodenal epithelium of broiler chicks, and affects the movement of water across the small intestinal epithelium in vitro. Comparative Biochemistry and Physiology 129A, 595-603.

Kettunen H, Peuranen S, Tiihonen K \& Saarinen M (2001b) Intestinal uptake of betaine in vitro and the distribution of methyl groups from betaine, choline, and methionine in the body of broiler chicks. Comparative Biochemistry and Physiology 128A, 269-278.

Kettunen H, Tiihonen K, Peuranen S, Saarinen MT \& Remus JC (2001c) Dietary betaine accumulates in the liver and intestinal tissue and stabilizes the intestinal epithelial structure in healthy and coccidia-infected broiler chicks. Comparative Biochemistry and Physiology 130A, 759-769.

Kidd MT, Ferket PR \& Garlich JD (1997) Nutritional and osmoregulatory functions of betaine. World's Poultry Science Journal 53, 125-139.

Kitt SJ, Miller PS, Lewis AJ \& Chen HY (1999) Effects of betaine and pen space allocation on growth performance, plasma urea concentration and carcass characteristics of growing and finishing barrows. Journal of Animal Science 77, Suppl. 1, 53.

Klasing KC, Adler KL, Remus JC \& Calvert CC (2002) Dietary betaine increases intraepithelial lymphocytes in the duodenum of coccidian-infected chicks and increases functional properties of phagocytes. Journal of Nutrition 132, 2274-2282.

Kuznetsov VV \& Shevyakova NI (1997) Stress response of tobacco cells to high temperature and salinity. Proline accumulation and phosphorylation of polypeptides. Physiologia Plantarum 100, 320-326.

Law RO \& Burg MB (1991) The role of organic osmolytes in the regulation of mammalian cell volume. In Advances of Comparative and Environmental Physiology, vol. 9, Volume and Osmolality Control in Animal Cells, pp. 189-225 [R Gilles, EK Hoffmann and L Bolis, editors]. New York: Springer Verlag.

Lawrence BV, Schinckel AP, Adeola O \& Cera K (2002) Impact of betaine on pig finishing performance and carcass composition. Journal of Animal Science 80, 475-482.

LeMieux FM, Southern LL \& Bidner TD (1996) Interactive effects of chromium tripicolinate, zinc oxide and (or) betaine on growth performance of weanling pigs. Journal of Animal Science 74, Suppl. 1, 184.

Le Rudulier D, Ström AR, Dandekar AM, Smith LT \& Valentine RC (1984) Molecular biology of osmoregulation. Science 224, $1064-1068$.

Löest CA, Drouillard EC, Titgemeyer EC, Hunter RD \& Wessel RH (1998) Betaine as a dietary supplement for finishing cattle. In Cattlemen's Day, Report of Progress 804, pp. 76-78. Manhattan, KA: Agricultural Experimental Station, Kansas State University

Löest CA, Titgemeyer EC, Drouillard JS, Blasi DA \& Bindel DJ (2001) Soybean hulls as a primary ingredient in forage-free diets for limit-fed growing cattle. Journal of Animal Science 79, 766-774.

Löest CA, Titgemeyer EC \& Greenwood RH (1999) Role of methionine as a methyl group donor in cattle. In Cattlemen's Day, Report of Progress 831, pp. 114-116. Manhattan, KA: Agricultural Experimental Station, Kansas State University.

Lowry KR, Izquierdo QA \& Baker DH (1987) Efficacy of betaine relative to choline as a dietary methyl donor. Poultry Science 66, 135.

McDevitt RM, Mack S \& Wallis IR (2000) Can betaine partially replace or enhance the effect of methionine by improving broiler growth and carcase characteristics? British Poultry Science $\mathbf{4 1}$ 473-480.

Matthews JO, Southern LL \& Bidner TD (2001a) Estimation of the total sulfur amino acid requirement and the effect of betaine in diets deficient in total sulfur amino acids for the weanling pig. Journal of Animal Science 79, 1557-1565.

Matthews JO, Southern LL, Bidner TD \& Persica MA (2001b) Effects of betaine, pen space, and slaughter handling method on growth performance, carcass traits, and pork quality of finishing barrows. Journal of Animal Science 79, 967-974.

Matthews JO, Southern LL, Higbie AD, Persica MA \& Bidner TD (2001c) Effects of betaine on growth, carcass characteristics, pork quality, and plasma metabolites in finishing pigs. Journal of Animal Science 79, 722-728.

Matthews JO, Southern LL, Pontif JE, Higbie AD \& Bidner TD (1998) Interactive effects of betaine, crude protein, and net energy in finishing pigs. Journal of Animal Science 76, 2444-2455.

Mitchell AD, Chappell A \& Knox KL (1979) Metabolism of betaine in the ruminant. Journal of Animal Science 49, 764-774.

Moeckel GW \& Lien YH (1997) Distribution of de novo synthetized betaine in rat kidney: role of renal synthesis of medullary betaine accumulation. American Journal of Physiology 272, F94-F99.

Moeckel GW, Shadman R, Fogel JM \& Sadrzadeh SMH (2002) Organic osmolytes betaine, sorbitol and inositol are potent inhibitors of erythrocyte membrane ATPases. Life Sciences 71, $2413-2424$

Mongin P (1976) Ionic constituents and osmolality of the small intestinal fluids of the laying hen. British Poultry Science 17, 383-392.

Nakanishi TR, Turner J \& Burg MB (1990) Osmoregulation of betaine transport in mammalian medullary cells. American Journal of Physiology 258, F1061-F1067.

National Research Council (1994) Nutrient Requirements of Poultry, 9th ed. Washington, DC: National Academy Press.

National Research Council (1998) Nutrient Requirements of Swine, 10th ed. Washington, DC: National Academy Press.

Neill AR, Grime DW, Snoswell AM, Northrop AJ, Lindsay DB \& Dawson RM (1979) The low availability of dietary choline for the nutrition of the sheep. Biochemical Journal 180, 559-565.

Overland M, Rorvik KA \& Skrede A (1999) Effect of trimethylamine oxide and betaine in swine diets on growth performance, carcass characteristics, nutrient digestibility, and sensory quality of pork. Journal of Animal Science 77, $2143-2153$.

Owen K, Nelssen J, Goodband R, Weeden T \& Blum S (1996) Effect of L-carnitine and soyabean oil on growth performance and body composition of early weaned pigs. Journal of Animal Science 74, 1612-1619.

Oyaas K, Ellingsen TE, Dyrset N \& Levine DW (1995) Transport of osmoprotective compounds in hybridoma cells exposed to hyperosmotic stress. Cytotechnology 17, 143-151.

Pesti GM, Harper AE \& Sunde ML (1979) Sulfur amino acid and methyl donor status of corn-soy diets for starting broiler chicks and turkey poults. Poultry Science 58, 1541-1547.

Peters-Regehr T, Bode JG, Kubitz R \& Haussinger D (1999) Organic osmolyte transport in quiescent and activated rat hepatic stellate cells (Ito cells). Hepatology 29, 173-180.

Petronini PG, Alfieri RR, Losi MN, Caccamo AE, Cavazzoni A, Bonelli MA, Borghetti AF \& Wheeler KP (2000) Induction of BGT-1 and amino acid system A transport activities in endothelial cells exposed to hyperosmolarity. American Journal of Physiology 279, R1580-R1589.

Petronini PG, de Angelis EM, Borghetti P \& Borghetti AF (1992) Modulation by betaine of cellular response to osmotic stress. Journal of Biochemistry 282, 69-73. 
Petronini PG, de Angelis EM, Borghetti AF \& Wheeler KP (1994) Osmolytically inducible uptake of betaine via amino acid transport system A in SV-3T3 cells. Biochemical Journal 300, 45-50.

Pettigrew JE \& Esnaola MA (2001) Swine nutrition and pork quality: a review. Journal of Animal Science 79, Suppl. E, E316-E342.

Puchala R, Zabielski R, Lesniewska P, Gralak V, Kiela P \& Barej W (1998) Influence of duodenal infusion of betaine or choline on blood metabolites and duodenal electrical activity in Friesian calves. Journal of Agricultural Science 131, 321-327.

Puchala RT, Sahlu MJ, Herselman JJ \& Davis SP (1995) Influence of betaine on blood metabolites of alpine and angora kids. Small Ruminant Research 18, 137-143.

Remus J, Virtanen E, Rosi L \& McNaughton J (1995) Effect of betaine on nutrient utilization of 21-day-old broilers during coccidiosis. In Proceedings of the 10th European Symposium on Poultry Nutrition, 15-19 October 1995, pp. 371-372. Antalya, Turkey: World Poultry Science Association.

Remus JC \& Quarles CL (2000) The effect of betaine on lesion scores and tensile strength of coccidia-challenged broilers. Poultry Science 79, Suppl. 1, 118.

Robinson SP \& Jones GP (1986) Accumulation of glycine betaine in chloroplasts provides osmotic adjustment during salt stress. Australian Journal of Plant Physiology 13, 659-668.

Rowling MJ, McMullen MH, Chipman DC \& Schalinske KL (2002) Hepatic glycine N-methyltransferase is up-regulated by excess dietary methionine in rats. Journal of Nutrition 132, 2545-2550.

Sakomura NK, Kimura ME, Junqueira OM \& Silva R (1996) Utilization of betaine in broiler rations. Ars Veterinaria 12, 86-94.

Schrama JW, Heetkamp MJW, Simmins PH \& Gerrits WJJ (2003) Dietary betaine supplementation affects energy metabolism of pigs. Journal of Animal Science 81, 1202-1209.

Schutte JB, de Jong J, Smink W \& Pack M (1997) Replacement value of betaine for DL-methionine in male broiler chicks. Poultry Science 76, 321-325.

Schwab U, Torronen A, Toppinen L, Alfthan G, Saarinen M, Aro A \& Uusitupa M (2002) Betaine supplementation decreases plasma homocysteine concentrations but does not affect body weight, body composition or rest energy expenditure in human subjects. American Journal of Clinical Nutrition 76, 961-967.

Shibata T, Akamine T, Nikki T, Yamashita H \& Nobukini K (2003) Synthesis of betaine-homocysteine S-methyl-transferase is continuously enhanced in fatty livers of thyroidectomized chickens. Poultry Science 82, 207-213.

Sidransky H \& Farber E (1960) Liver choline oxidase in man and in several species of animals. Archives of Biochemistry and Biophysics 87, 129-133.

Siljander-Rasi H, Peuranen S, Tiihonen K, Virtanen E, Kettunen H, Alaviuhkola T \& Simmins PH (2003) Effect of equi-molar dietary betaine and choline addition on performance, carcass quality and physiological parameters of pigs. Animal Science 76, $55-62$.

Simon J (1999) Choline, betaine and methionine interactions in chickens, pigs and fish (including crustaceans). World's Poultry Science Journal 55, 353-374.

Smith JW II, Nelssen JL, Goodband RD, Tokach MD, Richert BT, Owen KQ, Bergstrom JR \& Blum SA (1995) The effects of supplementing growing-finishing swine diets with betaine and (or) choline on growth and carcass characteristics. Journal of Animal Science 73, Suppl. 1, 83, Abstr.

Smith JW II, Owen KQ, Nelssen JL, Goodband RD, Tokach MD, Friesen KG, Lohrmann TL \& Blum SA (1994) The effects of dietary carnitine, betaine, and chromium nicotinate supplementation on growth and carcass characteristics in growing-finishing pigs. Journal of Animal Science 72, Suppl. $1,274$.

Snoswell AM \& Xue GP (1987) Methyl group metabolism in sheep. Comparative Biochemistry and Physiology 88B, $383-394$

Souffrant WB (1991) Endogenous nitrogen losses during digestion in pigs. In Proceedings of the 5th International Symposium on Digestive Physiology in Pigs, EAAP no. 54, pp. 147-166 [MWA Versteegen, J Huisman and LA den Hartog, editors]. Wageningen, The Netherlands: EAAP.

Southern LL, Brown DR, Werner DD \& Fox MC (1986) Excess of supplemental choline for swine. Journal of Animal Science 62 , 992-996.

Sowden MP, Collins HL, Smith HC, Garrow TA, Sparks JD \& Sparks CE (1999) Apolipoprotein mRNA and lipoprotein secretion are increased in McArdle RH-7777 cells by expression of betaine-homocysteine S-methyltransferase. Biochemical Journal 341, 639-645.

Sparks JD \& Sparks CE (1994) Insulin regulation of triacylglycerol-rich lipoprotein synthesis and secretion. Biochimia et Biophysica Acta 1215, 9-23.

Steinmetzer W (1972) Contribution to the biochemistry and use of the beet constituent betaine. Zucker 25, 48-57.

Stekol JA, Hsu PT, Weiss S \& Smith P (1953) Labile methyl group and its synthesis de novo in relation to growth of chicks. Biological Chemistry 203, 763-773.

Stryer L (1988) Biosynthesis of amino acids and heme. In Biochemistry, 3rd ed., pp. 575-626. New York: WH Freeman and Company.

Tan AW \& Ungar F (1979) Growth hormone effects on creatine uptake by muscle in the hypophysectomized rat. Molecular Cellular Biochemistry 25, 67-77.

Teeter RG, Remus JC, Belay T, Mooney M, Virtanen E \& Augustine P (1999) The effects of betaine on water balance and performance in broilers reared under differing environmental conditions. In Proceedings of the Australian Poultry Science Symposium, p. 165 [D Balnave, editor]. Sydney: University of Sydney Printing Service.

Tramacere M, Petronini PG, Severini A \& Borghetti AF (1984) Osmoregulation of amino acid activity in cultured fibroblasts. Experimental Cell Research 151, 70-79.

Tyler DD (1977) Transport and oxidation of choline by liver mitochondria. Biochemical Journal 166, 571-581.

Urbanczyk J (1997) An attempt to decrease pig carcass fatness by nutritive factors. Krmiva 39, 311-325.

Urbanczyk J, Hanczakowska E \& Swiatkiewycz M (1999) Betaine and organic chromium as the feed additives in pig nutrition. Annals of Warsaw Agricultural University, Animal Science 36, 133-140.

Urbanczyk J, Hanczakowska E \& Swiatkiewycz M (2000) The efficiency of betaine and organic chromium compounds according to fattening pig genotype. Biuletyn Naukowy Przemyslu Paszowego 39, 53-64.

van Lunen TA \& Simmins PH (2000) Dietary enzyme and betaine supplementation for young pigs. Canadian Journal of Animal Science 80, 755-756.

Virtanen E, McNaughton J, Rosi L \& Hall D (1993) Effects of betaine supplementation on intestinal lesion, mortality and performance of coccidian-challenged broiler chicks. In Proceedings of the 9th European Symposium on Poultry Nutrition, Jelenia, Göra, Poland, pp. 433-446. World's Poultry Science Association.

Virtanen E \& Rosi L (1995) Effects of betaine on methionine requirement of broilers under various environmental conditions. In Proceedings of the Australian Poultry Science Symposium, pp. 88-92. Sydney, NSW, Australia: University of Sydney. 
Wallis IR (1999) Dietary supplements of methionine increase breast meat yield and decrease abdominal fat in growing broiler chickens. Australian Journal of Experimental Agriculture 39, $131-141$.

Wang YZ (2000) Effect of betaine on growth performance and carcass traits of meat ducks. Journal of Zhejiang University Agricultural and Life Sciences 26, 347-352.

Wang YZ \& Xu ZR (1999) Effect of feeding betaine on weight gain and carcass trait of barrows and gilts and approach to mechanism. Journal of Zhejiang Agricultural University 25, 281-285.

Wang YZ, Xu ZR \& Chen ML (2000a) Effect of betaine on carcass fat metabolism of meat duck. Chinese Journal of Veterinary Science 20, 409-413.

Wang YZ, Xu ZR \& Feng J (2000b) Study on the effect of betaine on meat quality and the mechanism in finishing pigs. Scientia Agricultura Sinica 33, 94-99.

Warren LK, Lawrence LM \& Thompson KN (1999) The influence of betaine on untrained and trained horses exercising to fatigue. Journal of Animal Science 77, 677-684.

Warskulat U, Wettstein M \& Häussinger D (1995) Betaine is an osmolyte in RAW 264.7 mouse macrophages. FEBS Letters 377, 47-50.

Webel DM (1994) Effect of betaine supplementation on growth performance, carcass characteristics and nitrogen retention of finishing pigs. M.S. thesis, University of Illinois, Urbana.

Webel DM, McKeith FK \& Easter RA (1995) The effects of betaine supplementation on growth performance and carcass characteristics in finishing pigs. Journal of Animal Science 73, Suppl. 1, 82

Weigand E \& Kirchgessner W (1981) Betaine and glutamine acid contribution to nitrogen digestion and balance during feeding of vinasse to growing pigs. Archives of Animal Nutrition 31, $335-343$.

Weik C, Warskulat U, Bode J, Peters-Regehr T \& Häussinger D (1998) Comparable organic osmolytes in rat liver endothelial cells. Hepatology 27, 787-793.

Westberg JK (1951) Betaine in the Nutrition of Chickens and Turkeys. Chicago, IL: International Minerals and Chemical Corporation.

Wettstein M, Weik C, Holneicher C \& Häussinger D (1998) Betaine as an osmolyte in rat liver: metabolism and cell-to-cell interactions. Hepatology 27, 787-793.

Wiedmeier RD, Tanner BH, Bair JR, Shenton HT, Arambel MJ \& Walters JL (1992) Effects of a new molasses by-product, concentrated separator by-product, on nutrient digestibility and ruminal fermentation in cattle. Journal of Animal Science $\mathbf{7 0}$, 1936-1940.

Xing WB \& Rajashekar CB (2001) Glycine betaine involvement in freezing tolerance and water stress in Arabidopsis thaliana. Environmental and Experimental Botany 46, 21-28.

Xu ZR \& Feng J (1998) Effect of betaine on carcass characteristics and approach to mechanism of the effect in finishing swine. Acta Veterinaria et Zootechnica Sinica 29, 397-405.

Xu ZR, Wang MQ \& Huai MY (1999a) Approach of the mechanism of growth-promoting effect of betaine on swine. Chinese Journal of Veterinary Science 19, 399-403.

Xu ZR \& Yu DY (2000) Effect of betaine on digestive function of weaned piglets. Chinese Journal of Veterinary Science 20, 201-204.
Xu ZR, Yu DY \& Wang YZ (1999b) The effects of betaine on weanling piglets and its mechanism. Journal of Zhejiang Agricultural University 25, 543-546.

Xu ZR, Yu DY, Wang YZ \& Zhou LX (1999c) Effect of betaine on growth and digestive function of weaning piglets. Acta Agriculturae Zhejiangensis 11, 4.

Xu ZR \& Zhan XA (1998) Effects of betaine on methionine and adipose metabolism in broiler chicks. Acta Veterinaria et Zootechnica Sinica 29, 212-219.

Xue GP \& Snoswell AM (1985a) Comparative studies on the methionine synthesis in sheep and rat tissues. Comparative Biochemistry and Physiology 80B, 489-494.

Xue GP \& Snoswell AM (1985b) Regulation of methyl group metabolism in lactating ewes. Biochemistry International 11, 381-385.

Yalcin S, Ergun A \& Colpan I (1992) The effects of betaine supplementation on egg production and egg quality in laying hen. Veteriner Fakultesi Dergisi, Universitesi Ankara 39 , 325-335.

Yancey PH \& Burg MB (1989) Distribution of major organic osmolytes in rabbit kidneys in diuresis and antidiuresis. American Journal of Physiology 257, F602-F607.

Yao Z \& McLeod RS (1994) Synthesis and secretion of hepatic apolipoprotein B-containing lipoproteins. Biochimia et Biophysica Acta 1212, 152-166.

Yao Z \& Vance DE (1989) Reductions in VLDL but not HDL, in plasma of rats deficient in choline. Biochemistry and Cell Biology 68, 552-558.

Yao Z \& Vance DE (1990) Head group specificity in the requirement of phosphatidylcholine biosynthesis for very low density lipoprotein secretion from cultured hepatocytes. Biological Chemistry 264, 11373-11380.

Yu DY, Feng J \& Xu ZR (2001) Effects of betaine on fat and protein metabolism in different stages of swine. Chinese Journal of Veterinary Science 21, 200-203.

$\mathrm{Yu}$ DY \& Xu ZR (2000) Effects of methyl-donor on the performances and mechanisms of growth-promoting hormone in piglets. Chinese Journal of Animal Science 36, 8-10.

Zentek J (2002) Egg taint - a problem of practical importance. Lohmann Information 28, 3-6.

Zhan XA (2000) Studies on growth-promoting mechanism of betaine in broiler chickens. Acta Agriculturae Zhejiangensis 12, 209-212.

Zhan XA \& Xu ZR (1999) Effects of betaine on meat quality and mechanism of the effects in finishing broilers. Journal of Zhejiang University Agriculture and Life Science 25, 611-614.

Zhang F, Warskulat U, Wettstein M \& Häussinger D (1996) Identification of betaine as an osmolyte in rat liver macrophages (Kupffer cells). Gastroenterology 110, 1543-1552.

Zou XT (2001) Effects of betaine on endocrinology of laying hens and its mechanism of action. Chinese Journal of Veterinary Science 21, 300-303.

Zou XT \& Lu JJ (2002) Effects of betaine on the regulation of the lipid metabolism in laying hen. Agricultural Sciences in China 1, $1043-1049$.

Zou XT, Ma YL \& Xu ZR (1998) Effects of betaine and thyroprotein on laying performance and approach to mechanism of the effects in hens. Acta Agriculturae Zhejiangensis 10, $144-149$.

Zou XT, Xu ZR \& Wang YZ (2002) Effects of methylamino acids on growth performance of swine in different stages. Journal of Zhejiang University Agriculture and Life Sciences 28, 551-555. 